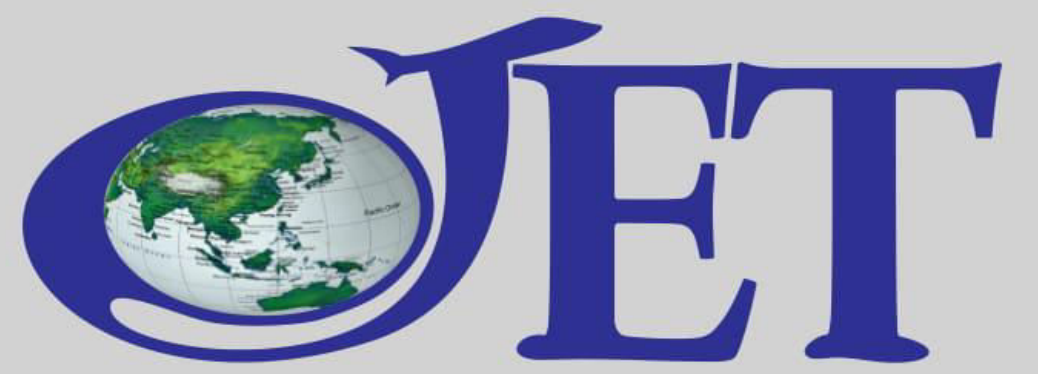

$a$

ISSN 20809628

Journal of English Teaching English Language Teaching

Volume 4, Number 1, February 2018

\title{
The Correlation between Self Assessment and Motivation in Learning English of the Second Grade Students of SMP Negeri 6 Palembang
}

\author{
Munjiana \\ munjiana@yahoo.com \\ STIE AKUBANK MULIA DARMA PRATAMA
}

\begin{abstract}
There is no single magical formula for motivating students. Many factors affect a given student's motivation to work and to learn. This study focused on the correlation between self assessment and motivation in learning English of the Second Grade students of SMPN 6 Palembang. There are four objectives in this study:1) to find out how the second grade students of SMP N6 Palembang motivation in learning English is; 2) to find out how the second grade students of SMPN 6 Palembang self assessment is; 3) to find out whether or not there is any significant correlation between self assesment and motivation in learning English of The Second Grade Students of SMPN6 Palembang; and 4) How much self assesment contribute to Students' motivation in learning English of The Second Grade Students of SMPN 6 Palembang. The data were collected by using questionnaire of 70 students that were taken as the samples by using random sampling. Then, it was analyzed by using Person's Product Moment Correlation Coefficient and the calculation was done by using SPSS (Statistical Package for Social Science). The result of the study showed that $72.9 \%$ of the second grade students of SMP N6 Palembang had good motivation in learning English and $67.1 \%$ of the second grade students of SMPN 6 Palembang also had good self assessment. In addition, the degree of correlation coefficient proved strong with the value of correlation 0.715 and self assessment itself contributed $51.1 \%$ to the students' motivation in learning English. From the above explanation, self assessment proved significantly has a very important role in learning language especially English.
\end{abstract}

Keywords: motivation, self assessment, English learning 


\section{Introduction}

Learning to communicate in another language takes a long time. It is one of the most challenging tasks the students are likely to undertake, and they can easily become discouraged and bored with it. Learning often becomes associated with drudgery instead of delight. Some students seem naturally enthusiastic about learning, but many need-or expect-their instructors to inspire, challenge, and stimulate them as stated by Ericksen (1978, p.3):

Effective learning in the classroom depends on the teacher's ability ... to maintain the interest that brought students to the course in the first place". Whatever level of motivation the students bring to the classroom will be transformed, for better or worse, by what happens in that classroom.

Unfortunately, there is no single magical formula for motivating students. Many factors affect a given student's motivation to work and to learn; interest in the subject matter, perception of its usefulness, general desire to achieve, self-confidence and self-esteem, as well as patience and persistence (Bligh, 1971; Sass, 1989). And, of course, not all students are motivated by the same values, needs, desires, or wants. Some of the students will be motivated by the approval of others, some by overcoming challenges. According to Brophy (1987), motivation to learn is a competence acquired "through general experience but stimulated most directly through modeling, communication of expectations, and direct instruction or socialization by significant others (especially parents and teachers)."

As one of the factors that influences in language learning, motivation takes crucial part especially in learning English. Hill (2000, p.8) defines motivation as moving in a direction of our choosing. It is also described as forces acting on within us that initiate and give it direction. Similarly motivation is also defined as something behind the actions; it acts as something that energizes behavior (Woolfolk \& Nicolich, 1980, p. 139). It means that motivation is something behind the actions; it acts as the energy which pushes somebody to do something. Then the motivation is defined as the push of mental forces to accomplish an action (Sthulman, 2006, p. 30)

Elliot et al (2000, p. 332) define motivation as an internal state that arouses us to action, pushes us in particular directions, and keeps us engaged in certain activities. Motivation is a process that is embedded in the ongoing stream behavior (Renchler, 1992, p. 16). Motivation is a cognitive frame work is based upon choices, decisions, plans, interests, goals, and calculations of 
success and failure (Woolfolk \& Nicolich, 1980, p. 231). It means somebody wants to learn English because he/she has motivation to choose his/her subject, his/her goal and his/her interest in some English materials.

Involving students in the assessment and evaluation process is an essential part of balanced assessment. When students become partners in the learning process, they gain a better sense of themselves as readers, writers, and thinkers. As students reflect on what they have learned and on how they learn, they develop the tools to become more effective learners. Students need to examine their work and think about what they do well and in which areas they still need help. Once students have reflected on their learning, they are ready to set new goals for themselves. As they work toward these goals, they should be encouraged to reflect on their learning journey at regular intervals. As students participate in the self-assessment process, they will have many opportunities to collect pieces of their writing and react to things they have read.

In general, Student Self-Assessment refers to training students to evaluate their own work for the purpose of improving it (Rolheiser \& Ross, 2000). To become capable evaluators of their work, students must have a clear target the opportunity to help create a definition of quality work feedback the opportunity to correct or self-adjust their work before they turn it in SSA also includes reflective activities in which students are prompted to consider the strengths and weaknesses of their work, make plans for improvement, or integrate the assignment with previous learning (Paris \& Ayres, 1994; Stiggins, 1997; Wiggins, 1998). To meet standards, students must understand the meaning of standards and be able to translate them into guidelines they can use. The process of leading students to express a standard in their own words in terms of observable criteria can produce goals for student work that are specific, understandable, and appropriately challenging (Rolheiser \& Ross, 2000).

The role of student self assessment in learning language especially English is very important. Self assessment will greatly influence whether students will avoid or pursue further learning in an area. This makes sense because self assessment promote critical, autonomous thinking with the goal of fostering actively engaged, self-regulated learners, not automatons (Stiggins, 1997; Wiggins, 1993).

The sample of this study is students of SMP N6 Palembang. There are nine classes from each grade. And each class consists of 35-40 students. When the writer had teaching practice in SMP N6 Palembang, she found that most of the students got fifty five score in English subject. 
Even though they got below score, on the next meeting there was no significant improvement from them. They still seem lazy to study and no progress or motivation in learning English.

Based on the explanation above, the writer is interested in conducting a research entitled “The Correlation between the Student Self Assesment and The Students Motivation in Learning English of The Second Grade Students of SMP N6 Palembang”.

\section{Research Methodology}

In this study, the writer used descriptive method, it means that this study describe the data as they are and interprets them on the basis of the writer's competence and knowledge. Popan and Sirotnik (1973, p. 4) state that descriptive method is to describe the data and summarize sets of numerical data such as test, score, ages and years of education. The writer used this method to describe or interpret the data about the correlation between the student self assesment and the students motivation in learning English of the second grade students of SMP N6 Palembang.

The population in this study is all of the second grade students of SMP Negeri 6. There are 346 students of the second grade students of SMP Negeri 6. As the samples, the writer takes $20 \%$ of the population; it means the writer takes 70 students of the second grade students for its samples. It is taken randomly for each group. Arikunto (2006, p.134) states that if there are so many subjects in population, just take $20-25 \%$ of the sample from the total population. But, if the population is between 100-150, and the researcher uses questionnaire, it is better for her/him to take all the population. In this study, the writer uses simple random sampling.

In this research, the writer made a questionnaire adapted from several resources such as (Hughes, B., Sullivan, H. \& Mosley, M. (1985). The questionnaire is in English and translated in Bahasa. There are 50 statements in the questionnaire. There are 30 statements for self assessment questionnaire and 20 statements of motivation questionnaire. It consists of four choices, they are; always true of me(3 Points), most of the time true of me (2 Points), sometimes true of me (1 Point) and never true of me(0 Points). The questionnaire is constructed by means of Likert Scale. Students rated themselves on a 3 point Likert Scale. Likert Scale items are most often used to investigated how respondents rate a series of statements by having them circle or otherwise mark numbered categories (for instance, $1 \begin{array}{llll}1 & 2 & 3 & 4\end{array}$ ). Likert Scale is useful for gathering 
respondents' feelings, opinions, attitudes, etc. on any language-related topics (Brown, 2000, p.18). The score are put quantitatively 3,2 , and 1 .

\section{Findings and Discussion}

The questionnaire consisted of 47 items, 28 items about self assessment and 19 items about motivation. The score were 3, 2, and 1. The range score was from always to never. Based on the table of frequency result, it can be seen that on categories of assessment questionnaires there was only one student (1.4\%) was poor, there were sixteen students $(22.9 \%)$ were fair, forty seven students $(67.1 \%)$ were good and six students $(8.6 \%)$ were very good. In categories of motivation questionnaire, no one poor $(0 \%)$, eight students $(11.4 \%)$ were fair, fifty one students $(72.9 \%)$ were good, and there were eleven students (15.7\%) were very good.

\section{Statistical Analysis}

There were two statistical analyses used by the writer in this study; (1) the correlation between self assessment and motivation (2) the contribution of self assessment to the students' motivation in learning English.

\section{The Correlation between Self Assessment and Motivation in Learning English}

It is shown in the table that correlation is significant at the 0.01 level or if $\mathrm{P}_{\text {calculate }}<$ 0.05 so it means that there is any significant correlation. The table below also shown that significant value $(\mathrm{P})$ is 0.000 and the value of correlation is 0.715 . Based on the degree of correlation coefficient (Sugiyono, 2001) the range between 0.60-0.799 is strong; therefore, it can be concluded that there was strong correlation between self assessment and motivation in learning English.

Table 1:

The Correlation between Self Assessment and Motivation

\begin{tabular}{|ll|r|r|}
\hline & & Asses sment & Motivation \\
\hline Asses sment & Pearson Correlation & 1 &, $715^{* *}$ \\
& Sig. (2-tailed) & &, 000 \\
& $\mathrm{~N}$ & 70 & 70 \\
\hline Motivation & Pearson Correlation &, $715^{* *}$ & 1 \\
& Sig. (2-tailed) &, 000 & \\
& $\mathrm{~N}$ & 70 & 70 \\
\end{tabular}

${ }^{* *}$. Correlation is significant at the 0.01 level (2-tailed). 


\section{The Contribution of Self Assessment to the Students Motivation in Learning English}

The contribution of self assessment here can be seen from $R_{\text {square. }} R_{\text {square is }} 0.511$ or $51,1 \%$ so it can be concluded that self assessment has $51.1 \%$ contribution to the students motivation in learning English.

\section{Discussion}

Some studies about student's self assessment and motivation in learning languages also conducted by some researchers. Hattie (2008) conducted a comprehensive review of 800 metaanalyses related to education. He found that self-reported grades (a weak form of self-assessment where students simply predict their own grades and then try to achieve them) were one of the single-most important strategies for improving student achievement. Self-report grades were found to have a significant effect size (d 1.44), the highest of the 138 impact factors identified (Hattie, 2008) and considerably higher than the average effect size in his study (d 0.40). Despite the potential in terms of motivation and achievement, self-report and self-assessment has also been severely criticised, particularly as an accurate form of assessment. For example, Janssenvan Dieten (1989) found a disappointing lack of correlation between self-assessment scores and test scores for Dutch as a second language, which was further triangulated with teachers' ratings. Blanche (1990) reported mixed findings in his study of French learners, noting the fact that overall the students displayed an impressive ability to self-assess accurately, and yet he also noted that learners were far less able to predict their oral achievement (vocabulary and grammar) grades. Jafarpur (1991) and Babaii, Taghaddomi, and Pashmforoosh (2015) found that there was a lack of consistency between learners' self-assessments and those of the teacher, indicating that self-assessment is unreliable as a method of accurate proficiency measurement, although Butler and Lee (2010) found that such discrepancies could be reduced with learner training. Conversely, Griffee (1998) has reported a positive correlation between students' self-assessment and 
teachers' evaluations, particularly among higher-level learners, which is further corroborated by the meta-study of self-assessment validity conducted by Ross (1998). Heilenman (1990) tested the validity of self-assessment using positively and negatively worded questions using a split ballot paper to test response effects. She concludes that both groups still tended to over-estimate their proficiency, although this was particularly salient amongst less experienced learners. However, other findings have revealed that self-assessment scores are reliable, for example Bachman and Palmer (1989), who found self-measures to be both reliable and valid measures of communicative competence. Peirce, Swain, and Hart (1993) found a correlation, although it was admittedly a weak one. Such varied findings cast doubt on the validity of using self-assessment scores as part of learners' final course scores. Most of the studies discussed above attempt to examine the validity and reliability of students' self-assessments of their own language ability, something which is notoriously difficult even for experts in language assessment. It is not really surprising that discrepancies exist between one type of rating and the other, and the large number of variables across each study makes direct comparison and conclusive generalisations difficult. However, all of these studies are positive about self-assessment as a tool for learning, even when they report negative correlations in their results:

The main purpose of self-assessment, however, is not its application for selection, but its positive influence on the learning process, if applied meaningfully and trained well.

(Janssen-van Dieten, 1989, p. 44)

\section{Conclusion}

After analyzing the results of the study, the writer found that the role of student self assessment in learning language especially English is very important. Self assessment will greatly influence whether students will avoid or pursue further learning in an area. This makes sense because self assessment promote critical, autonomous thinking with the goal of fostering actively engaged, self-regulated learners, not automatons. Students step back from the learning process to think about their language learning strategies and their progress as language learners. Such self assessment encourages students to become independent learners and can increase their motivation. 
In self assessment strategy, teacher also has important role in giving a good feedback to the students while doing self assessment. Teachers can also invite students to contribute to the choice of assessment tasks, the rubric that describes levels of proficiency, or the scoring procedure. Allowing students to work cooperatively with teachers in these areas appears to help students internalize the standard and feel more ownership of the assessment.

\section{References}

Arikunto, S. (2006). Prosedur Penelitian: Suatu Pendekatan Praktek. Jakarta: PT. Rineka Cipta.

Babaii, E., Taghaddomi, S., \& Pashmforoosh, R. (2015). Speaking self-assessment: Mismatches between learners' and teachers' criteria. Language Testing, Advance online publication, July 1, 2015. doi: 10.1177/0265532215590847.

Bachman, L. F., \& Palmer, A. S. (1989). The construct validation of self-ratings of communicative language ability. Language Testing, 6(1), 14-29. doi:10.1177/026553228900600104.

Blanche, P. (1990). Using standardized achievement and oral proficiency tests for selfassessment purposes: The DLIFLC study. Language Testing, 7(2), 202-229. doi: $10.1177 / 026553229000700205$

Bligh, D. A. (1971). What's the Use of Lecturing?. England, Devon: University of Exeter.

Brophy, J. (1987). On motivating students ( Occasional Paper No. 101). East Lansing, MI: Institute for Research on Teaching, Michigan State University.

Brown, H. Douglas. (2000). Principles of Language Learning and Teaching. USA: San Francisco State University.

Butler, Y. G., \& Lee, J. (2010). The effects of self-assessment among young learners of English. Language Testing, 27(1), 5-31. doi: 10.1177/0265532209346370.

Elliott, S.N., Kratochwill, T.R., Littlefield Cook, J. \& Travers, J. (2000). Educational psychology: Effective teaching, effective learning (3rd ed.). Boston, MA: McGraw-Hill College.

Ericksen, S. C. (1978). The Lecture, Memo to the Faculty. Ann Arbor: Center for Research on Teaching and Learning, University of Michigan.

Griffee, D. T. (1998). Classroom self-assessment-A pilot study. JALT Journal, 20(1), 115-125.

Hattie, J. (2008). Visible learning : A synthesis of over 800 meta-analyses relating to achievement. London: Routledge. 
Heilenman, K. L. (1990). Self-assessment of second language ability: The role of response effects. Language Testing, 7(2), 174-201. doi: 10.1177/026553229000700204

Hill, J. R. (2000). Measurement and evaluation in the classroom. Columbus, OH: Merrill.

Hughes, B., Sullivan, H. \& Mosley, M. (1985). External evaluation, task difficulty, and continuing motivation, Journal of Educational Research, 78, 210-215.

Jafarpur, A. (1991). Can naive EFL learners estimate their own proficiency? Evaluation \& Research in Education, 5(3), 145-157. doi: 10.1080/09500799109533306.

Janssen-van Dieten, A.-M. (1989). The development of a test of Dutch as a second language: The validity of self-assessment by inexperienced subjects. Language Testing, 6(1), 3046. doi: 10.1177/026553228900600105.

Paris, S., \& Ayres, L. (1994). Becoming reflective students and teachers. D.C.: American Psychological Association.

Peirce, B. N., Swain, M., \& Hart, D. (1993). Self-assessment, French immersion, and locus of control. Applied Linguistics, 14(1), 25-42. doi: 10.1093/applin/14.1.25

Popham, W., \& Sirotnik. (1973). Establishing instructional goals. Englewood Cliffs, NJ: Prentice- Hall.

Renchler. (1992). Emotions in nondirected text learning. Learning and Individual Differences, 2(1), 1-17.

Rolheiser, C., \& Ross, J. A. (2000). Student self-evaluation-What do we know? Orbit, 30(4), 33-36.

Ross, J. A., Rolheiser, C., \& Hogaboam-Gray, A. (2000). Effects of self-evaluation training on narrative writing. Assessing Writing, 6(l), 107-132.

Ross, S. (1998). Self-assessment in second language testing: A meta-analysis and analysis of experiential factors. Language Testing, 15(1), 1-20. doi: 10.1177/026553229801500101

Sass, E. J. (1989). Motivation in the College Classroom: What Students Tell Us. Teaching of Psychology, 16(2), 86-88.

Sugiyono. (2001). Metode Penelitian Administrasi. Bandung: Penerbit Alfabeta Bandung.

Stiggins, R. (1997). Student-centered classroom assessment (2nd ed.). Upper Saddle River, NJ: Prentice-Hall.

Sthulman, L. S. (2006). Foreword to K. Hammerness, SEEING THROUGH TEACHERS' EYES: PROFESSIONAL IDEALS AND CLASSROOM PRACTICES. New York: Teachers College Press. 
Wiggins, G. (1998). Educative assessment: Designing assessments to inform and improve student Performance. San Francisco: Jossey-Bass.

Woolfolk, A. E., \& Nicolich, L. (1980). Educational psychology for teachers (2nd ed.). Englewood Cliffs, NJ: Prentice-Hall. 